\title{
Creativity, Critical Thinking, and Academic Performance in Students University During Virtual Learning
}

\author{
Bagus Hary Prakoso* \\ Center of Assessment and Learning \\ Ministry of Education and Culture \\ Jakarta, Indonesia \\ *bagus.hary@kemdikbud.go.id \\ Lidwina Felisima Tae \\ Faculty of Educational Sciences \\ Timor University, Kefamenanu \\ East Nusa Tenggara, Indonesia \\ lidwinafelisima@unimor.ac.id
}

\author{
Zulmi Ramdani \\ Faculty of Psychology \\ UIN Sunan Gunung Djati Bandung \\ Bandung, Indonesia \\ zulmiramdani@uinsgd.ac.id \\ Lucky Nindi Riandika M. \\ Faculty of Education and Social Sciences \\ Universitas Indraprasta PGRI \\ Jakarta, Indonesia \\ riandika.lucky29@gmail.com
}

\begin{abstract}
Optimization of virtual learning is not only supported by the availability of adequate facilities but also through developing student potential in the aspects of creativity and critical thinking. Both of these aspects are absolutely needed by students to adapt to the learning process, one of which will also affect their learning achievement improvement. This study aims to look at the relationship between creativity, critical thinking, and student academic performance during online learning. The quantitative research design used in this study involved 168 student respondents who attended online lectures and were selected using purposive sampling technique. The results showed that creativity has a significant and linear relationship with critical thinking disposition, where the higher a person's creativity, the higher their critical thinking and vice versa. Besides that, simultaneously creativity and critical thinking can be one of the factors that determine student academic performance. Thus, this study shows that by considering these three variables in learning, it is expected to be able to produce optimal learning outcomes, especially in virtual learning.
\end{abstract}

Keywords-academic performance, creativity, critical thinking, critical thinking disposition, virtual learning

\section{INTRODUCTION}

To get an optimal learning achievement, there are many factors that must be considered by students in order to achieve their best learning outcomes. The supporting factors are not only about the accessibility and the facilities provided but also in terms of internal factors that come from the student's own personality. The factors that determine the success of students in learning include (1) a planned education system and curriculum; (2) the availability of facilities and easy accessibility in the schools; (3) competent teachers in various aspects, and (4) students' individual characters and abilities [14]. Between these factors, individual factors are considered as the significant factors that have a major contribution on students learning achievement.

This individual factor refers to the internal resources in the form of disposition, characteristics, attitudes, behavior or other abilities possessed by students [5]. These aspects will lead a person to achieve certain goals that have been targeted. The factors of creativity and critical thinking are considered as factors that can determine how a student develop and optimize himself [6,7]. Creativity refers to the ability to create new things and new ideas in order to find out the alternative solutions when facing the learning problems. Likewise, with critical thinking, creativity is used as an important power for someone to develop the information they acquire. There have been many studies that have tried to link the role of creativity and critical thinking, where most of them agreed that with these two aspects, a person can achieve an optimal learning achievement $[8,9]$.

Although there have been many previous studies that explained the relationship between creativity and critical thinking in achieving one's learning achievement, not much is known about the relationship between these three variables in virtual learning during the Covid-19 pandemic. This study aims to see the relationship of the three variables tested, especially in the context of virtual learning during the pandemic. Therefore, the researchers assume that there is a significant relationship between these three variables. Henceforth, the relationship 
between these variables can be seen in the results and discussion.

\section{LITERATURE REVIEW}

\section{A. Creativity Theory}

Creativity is closely related to divergent thinking pattern where an individual is able to produce more than one solution in solving a particular problem [10]. An individual's level of creativity enables him to combine unrelated topics in unique and different ways to find new and flexible ideas [11]. Creativity is also related to the originality of ideas, openness to new experiences, willingness to accept something new and different or perhaps unreasonable, willingness to accept risks in thoughts and actions, and sensitive to the beauty of the character of these ideas [12]. Warren et al. [10] suggested that three factors that could influence creativity are fluency (number of ideas), flexibility (diversity of ideas), and authenticity (new and useful ideas). In addition, according to $[7,13]$, two factors that can predict the level of creativity in a student are the attitude of openness to new experiences and intrinsic motivation that comes from within the student.

The level of creativity owned by a student is influenced by several factors including the environmental influences that come from inside or outside the school [7]. According to Gralewski and Karwowski [14], family socio-economic status and extrinsic support (such as intellectual activities at home and the availability of books at home) have a positive effect on students' creativity levels, but only during the early stages (when they were children). The influence of these external factors no longer has an effect when a student grows up. Meanwhile, the extrinsic motivation from parents, for example in helping children identify their mistakes rather than giving gifts, was found to have no effect on the development of a child's creativity. A supportive social environment can influence student's creativity. Students who get support from the school to develop their creativity have more creative selfefficacy and become creative individuals [15]. However, student's creativity can be hampered by factors such as social relationships, cultural views, or the environment and obstacles that come from within a person [16].

\section{B. Critical Thinking Disposition}

One of the determining factors for the student's success in the learning process is the level of critical thinking. Until now, many studies have tried to measure the level of critical thinking of the students or the teachers $[15,17,18]$. By using the California Critical Thinking Disposition Inventory (CCTDI) instrument developed by Facione et al. [19] and Facione [20], they found that students' critical thinking level was not influenced by the length of study time (semester level). Instead, the level of critical thinking of students is influenced by the type of major that students are studying. They found that students studying Mathematics had a higher level of critical thinking than students studying Turkish. Furthermore, a study has been conducted on 230 lecturers in Spain and Latin
Americans in which they were asked to share their views on the types of teaching methods that could improve students' critical thinking. The results showed that there were 3 methods most proposed by the lecturers, namely: Oral and Written Reflection and Argumentation; Reading, Analysis, and Synthesis of Resources; and Case Studies [21].

\section{Academic Performance}

Student learning achievement is one of the outcomes to be achieved after the learning process takes place. Student academic performance is influenced by several factors, including factors that come from within the student and those from outside the student with a large portion coming from within the student [22]. Factors that come from within students include student learning independence where students are able to learn independently without the help of others [23]. In addition, factors that come from inside the students are also determined by the level of student motivation to learn where students with high learning motivation tend to have persistent enthusiasm, never give up, and actively seek new knowledge which in the end could determine good learning achievement [24].

Meanwhile, the external factors that could affect student's academic performance are student's social environment which can be divided into three, namely the family, school and community environment [25]. So it can be concluded that a conducive social environment can support a student to achieve better learning achievement, while a less supportive environment, such as the attitude of parents who do not pay too much attention to children's learning development or conflicts in the family can reduce student achievement in school [26].

\section{Correlation between Variables}

Creativity and critical thinking are the two variables most associated with student academic performance. Hansenne and Legrand [27] found that creativity in a person can predict student achievement in school. In line with this result, D'Alessio et al. [28] also showed a close relationship between the level of critical thinking and academic performance where students who have a high level of critical thinking tend to have better academic performance. This was also reinforced by the statistical analysis of Fong et al. [9] which also found a positive and significant relationship between student creativity and academic performance. Furthermore, a study using instruments from of Watson Glaser Critical Thinking Appraisal (WGCTA) was used to see the impact of critical thinking on academic performance in 1620 executive MBAs. This study found that critical thinking had a positive impact on the average academic performance of the respondents [28].

Chan and Yuen [29] found that the teachers who usually teach classes with genius students have higher creative scores. This is because these teachers have confidence about their creativity, creative personality, and in the end influence their creative behavior which then affects the academic performance of their students in the classroom. If viewed from a personal aspect, students who are independent, expressive, and have 
high aspirations for their academic performance are more likely to have high levels of creativity [13]. Students' imagination can also become a mediator variable that mediates the relationship between creativity, personality and academic performance [30].

\section{METHODS}

This study uses a quantitative approach that aims to test whether there is a relationship between the variables being tested. The variables tested are creativity, critical thinking disposition and academic performance. Researchers assume that there is a relationship between the three variables.

\section{A. Sample}

Respondents in this study were students at several campuses who were selected using purposive sampling technique. The characteristics of the existing respondents were students who are received online lectures due to this pandemic. No gender categorization or other differences were specific to this study.

\section{B. Instruments}

This study used three measuring instruments that have been validated before. The three measuring tools used in this study were creativity instrument, critical thinking instrument and student's Grade Point Average (GPA). The first instrument was the creativity scale developed by Peterson and Seligman [31] Banicki [32]. The creativity instrument was validated into the Indonesian context by Fahmi and Ramdani [1]. There were 10 items used to measure the condition of the respondent's creativity. The creativity instrument used in this study has a reliability coefficient value above .7 so it is suitable to be used in this study. The second instrument used in this research was a critical thinking disposition instrument which has been modified and developed by Ramdani et al. [33] in the form of self-report on a Likert scale. This instrument measures 7 dimensions on these attributes, namely truth-seeking, openmindedness, systematic, inquisitiveness, cognitive maturity, self-confidence and analyticity. While the third measuring instrument was academic performance which was seen from the last respondent's GPA.

\section{Collecting and Analyzing Data}

The tidied up questionnaire containing the three measuring instruments was then made in an online version according to the existing scheme. Then online questionnaires were distributed to respondents according to the sampling technique used. The data collection process was carried out for approximately 1 month from June to July 2020. After that, the data was tabulated and analyzed descriptively using RASCH analysis to see the strength of existing measuring instruments and correlational analysis with Pearson Correlation to see the existing relationship of the three variables.

\section{RESULTS AND DISCUSSIONS}

A good instrument has valid and reliable criteria. The instrument used in this study was Creative Thinking Instrument to measure creative thinking skill which has 10 items. Based on the RASCH modeling analysis shown in the image below, it could be seen that there were 8 invalid items for item number $1,2,3,4,6,7,8$, and 9 . Valid items were only found in items number 5 and 10 . The validity of items of creative thinking instrument show in figure1.

\begin{tabular}{|c|c|c|c|c|c|c|c|c|c|c|c|c|c|}
\hline | ENTRY & TOTAL & TOTAL & & MODEL | & & FIT & OU & FIT & |PT-MEA & SURE | & | EXACT & MATCH| & \\
\hline | NUMBER & SCORE & COUNT & MEASURE & S.E. I & |MNSQ & ZSTD| & MNSQ & ZSTD| & |CORR. & EXP.| & OBS\% & EXP\%| & ITEM \\
\hline 8 & 510 & 168 & .82 & .11| & 1.30 & $2.3 \mid$ & 1.38 & $2.9 \mid$ & .57 & $.66 \mid$ & 57.1 & $53.4 \mid$ & V8_A \\
\hline 6 & 521 & 168 & .69 & |11| & | .54 & $-4.6 \mid$ & .56 & $-4.4 \mid$ & .74 & $.66 \mid$ & 67.3 & $53.9 \mid$ & V6_A \\
\hline 7 & 526 & 168 & .64 & $.11 \mid$ & . .62 & $-3.6 \mid$ & .62 & $-3.7 \mid$ & .68 & $.66 \mid$ & 67.3 & 54.0 & V7_A \\
\hline 1 & 566 & 168 & .15 & |11| & | .78 & -2.00 & .75 & $-2.3 \mid$ & .72 & $.65 \mid$ & 69.0 & 54.2 & CREATIVI| \\
\hline 10 & 583 & 168 & -.07 & .11| & | .85 & $-1.3 \mid$ & .86 & $-1.3 \mid$ & .69 & $.64 \mid$ & 59.5 & 54.7| & V10_A \\
\hline 9 & 584 & 168 & -.08 & $.11 \mid$ & 1.42 & $3.1 \mid$ & 1.42 & $3.2 \mid$ & .58 & $.64 \mid$ & 50.0 & 54.7| & V9_A \\
\hline 2 & 585 & 168 & -.10 & .11| & |1.49 & 3.7| & 1.52 & 3.9 & .55 & $.64 \mid$ & 50.6 & 54.7| & V2_A \\
\hline 5 & 595 & 168 & -.23 & .12 & .76 & -2.2 & .76 & -2.2 & .70 & $.64 \mid$ & 54.2 & $54.8 \mid$ & V5_A \\
\hline 3 & 635 & 168 & -.78 & .12| & | .99 & $-.1 \mid$ & .97 & $-.3 \mid$ & .70 & .63| & 65.5 & $55.9 \mid$ & V3_A \\
\hline 4 & 653 & 168 & -1.04 & $.12 \mid$ & |1.51 & $4.1 \mid$ & |1.48 & 3.7ㅇ & .63 & $.62 \mid$ & 54.2 & $56.3 \mid$ & V4_A \\
\hline MEAN & 575.8 & 168.0 & .00 & |11| & |1.02 & .00 & |1.03 & $.0 \mid$ & & & 59.5 & 54.7| & \\
\hline S.D. & 44.7 & .0 & .58 & $.01 \mid$ & | .35 & 3.0 이 & | .36 & 3.00 & & & 6.9 & .81 & \\
\hline
\end{tabular}

Fig. 1. Validity of items of creative thinking instrument.

Based on the RASCH analysis above, it could be clearly seen that eight items have a standard score that do not match the standard RASCH modeling analysis. This could be possible because some items need to be revised especially those that contain the less effective sentences that need to be adjusted with the instrument blueprint. This instrument has a moderate measurement of creative thinking. Some examples of sentences that are less effective are as follows; (1) Need to be revised 
with "my strength is to present new and unique ideas". (2) The sentences were too long and less effective, should be revised

with "when people are told about how to do something, I already have a more effective way of my own".

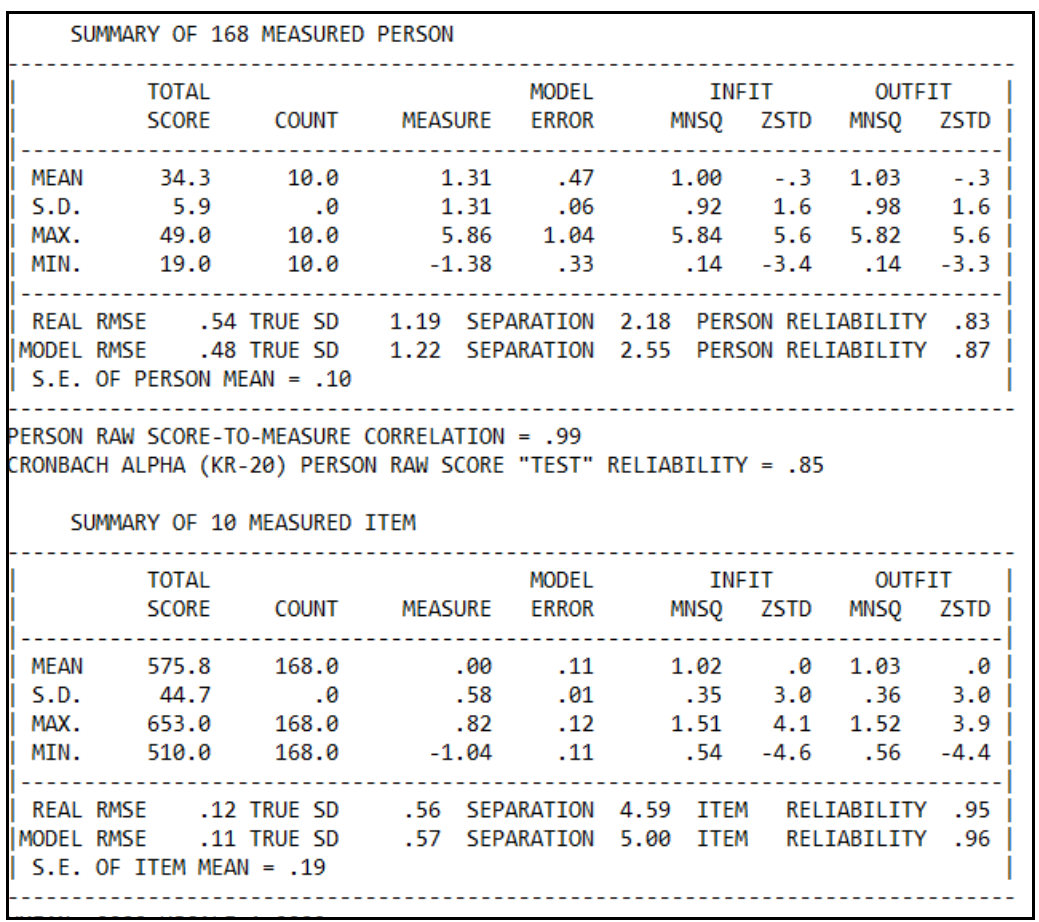

Fig. 2. Reliability of items of creative thinking instrument.

From figure 2 reliability of the instrument used was high, with a reliability coefficient of .85 and strengthened by the reliability of the items on the instrument used at .96 , while the consistency of respondents in answering the instrument items used was .87 with a good category. The results of this reliability test indicate that the items answered by 168 respondents with good consistency. Furthermore, based on the analysis of validity and reliability, it was found that creative thinking instrument has eight invalid items out of ten items, while the critical thinking disposition has four invalid items out of 21 items. Figure 3 show validity of critical thinking disposition

\begin{tabular}{|c|c|c|c|c|c|c|c|c|c|c|c|c|c|}
\hline \multirow{2}{*}{$\begin{array}{l}\text { ENTRY } \\
\text { NUMBER }\end{array}$} & \multirow{2}{*}{$\begin{array}{l}\text { TOTAL } \\
\text { SCORE }\end{array}$} & \multirow{2}{*}{$\begin{array}{l}\text { TOTAL } \\
\text { COUNT }\end{array}$} & \multirow[b]{2}{*}{ MEASURE } & \multicolumn{3}{|c|}{ MODEL | INFIT } & \multicolumn{2}{|c|}{ OUTFIT } & \multicolumn{2}{|c|}{ |PT-MEASURE } & \multicolumn{2}{|c|}{ | EXACT MATCH| } & \multirow[b]{2}{*}{ ITEM } \\
\hline & & & & S.E. I & IMNSQ & ZSTD| & MNSQ & ZSTD & |CORR. & EXP. $\mid$ & OBS\% & EXP\%| & \\
\hline 3 & 566 & 168 & 1.46 & .10| & |1.04 & & 1.23 & 1.7 & .51 & .64 & 46.4 & $53.5 \mid$ & CTD3 \\
\hline 14 & 610 & 168 & .93 & .11 & 1.07 & $.6 \mid$ & 1.17 & 1.4 & .57 & .61 & 58.4 & $56.4 \mid$ & CTD14 \\
\hline 8 & 613 & 168 & .89 & .12 & .89 & $-.8 \mid$ & .99 & .0 & .61 & .61 & 53.6 & $56.9 \mid$ & CTD8 \\
\hline 16 & 615 & 168 & .86 & .12 & .75 & -1.9 & .83 & -1.5 & .68 & .61 & 68.7 & 57.01 & CTD16 \\
\hline 10 & 630 & 168 & .66 & .12 & .92 & $-.6 \mid$ & 1.00 & .0 & .60 & $.60 \mid$ & 62.0 & $57.6 \mid$ & CTD10 \\
\hline 12 & 637 & 168 & .55 & .12| & |1.01 & .11 & 1.07 & .6 & .62 & $.60 \mid$ & 59.6 & $57.9 \mid$ & CTD12 \\
\hline 15 & 638 & 168 & .54 & $.12 \mid$ & 1.16 & 1.2 & 1.18 & 1.5 & .60 & .60 & 62.7 & $57.9 \mid$ & CTD15 \\
\hline 18 & 654 & 168 & .30 & $.12 \mid$ & 1.68 & $4.6 \mid$ & 1.64 & 4.6 & .50 & .59 & 60.8 & $58.8 \mid$ & CTD18 \\
\hline 17 & 663 & 168 & .16 & .13| & | . .72 & -2.5 & .72 & -2.6 & .65 & .59 & 67.5 & 59.01 & CTD17| \\
\hline 7 & 664 & 168 & .14 & .13| & 1.30 & $2.3 \mid$ & 1.34 & 2.7 & .48 & .59 & 59.0 & $59.0 \mid$ & CTD7 \\
\hline 13 & 673 & 168 & .00 & .13| & .83 & -1.5 & .85 & -1.3 & .62 & .58 & 63.3 & 59.21 & CTD13 \\
\hline 19 & 676 & 168 & -.05 & .13| & .91 & $-.7 \mid$ & .91 & -.7 & .60 & .58 & 60.8 & $59.2 \mid$ & CTD19| \\
\hline 5 & 686 & 168 & -.22 & .13| & .64 & $-3.7 \mid$ & .65 & -3.3 & .66 & $.57 \mid$ & 71.1 & $59.5 \mid$ & CTD5 \\
\hline 11 & 691 & 168 & -.31 & .13| & .81 & -1.8 & .82 & -1.6 & .64 & .56 & 66.9 & $59.4 \mid$ & CTD11 \\
\hline 2 & 694 & 168 & -.36 & .13| & .80 & -1.9 & .81 & -1.6 & .58 & .56 & 60.8 & $59.5 \mid$ & CTD2 \\
\hline 1 & 699 & 168 & -.44 & .13| & 1.32 & $2.7 \mid$ & 1.28 & 2.2 & .54 & .56 & 63.3 & $59.4 \mid$ & CTD1 \\
\hline 4 & 707 & 168 & -.58 & .13| & 1.10 & $.9 \mid$ & 1.01 & .1 & .61 & .55 & 59.0 & $59.7 \mid$ & CTD4 \\
\hline 9 & 710 & 168 & -.64 & |13| & 1.11 & $1.0 \mid$ & 1.03 & .3 & .59 & .55 & 63.3 & 60.01 & CTD9 \\
\hline 21 & 738 & 168 & -1.17 & .14| & 1.22 & 2.01 & 1.14 & 1.0 & .50 & $.51 \mid$ & 69.3 & $63.3 \mid$ & CTD21 \\
\hline 6 & 743 & 168 & -1.27 & .14| & 1.12 & $1.1 \mid$ & 1.07 & .5 & .52 & .51 & 66.9 & $64.3 \mid$ & CTD6 \\
\hline 20 & 751 & 168 & -1.44 & .15| & |1.09 & $.8 \mid$ & |1.04 & .3 & .50 & .50 & 67.5 & $65.5 \mid$ & CTD20 \\
\hline MEAN & 669.4 & 168.0 & .00 & .13| & $\mid 1.02$ & |1| & 1.04 & .2 & & & 62.4 & 59.21 & \\
\hline S.D. & 47.0 & .0 & .76 & $.01 \mid$ & | .24 & $1.9 \mid$ & | .22 & 1.8 & & & 5.5 & $2.6 \mid$ & \\
\hline
\end{tabular}

Fig. 3. Validity of critical thinking disposition. 
Based on the analysis result above, it can be seen that item number $5,7,17$, and 18 were found to invalid items when used in measuring critical thinking skills. While the result of reliability shows a very high category with a reliability coefficient of .91 (See figure 4).

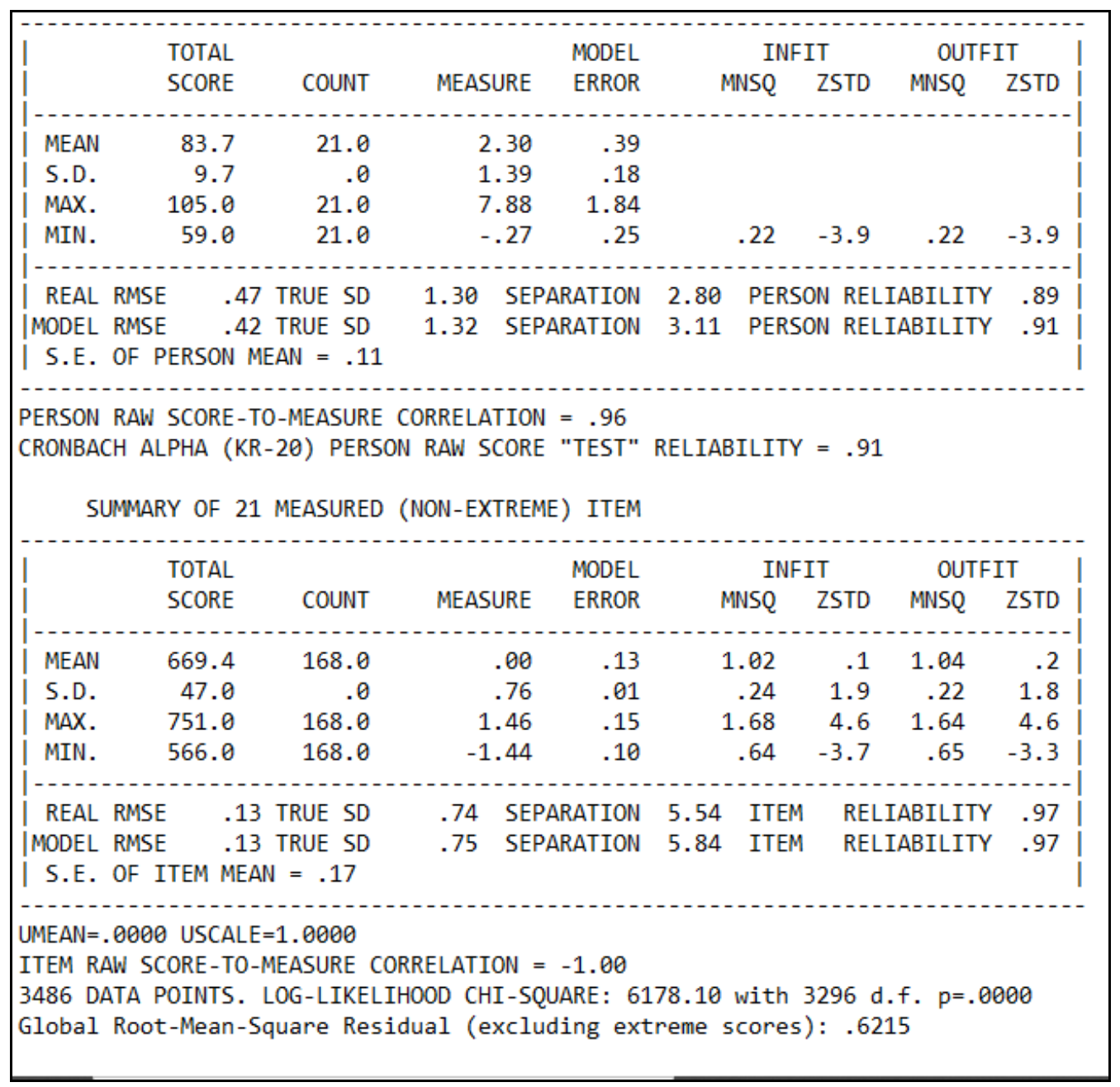

Fig. 4. Reliability of ctitical thinking disposition.

Based on the picture above, it shows that the consistency of the respondent in answering the item was indicated by a correlation of .91, while the reliability of the item itself is also in the very high category, namely .97 . Furthermore, after the researchers ensure that instrument used meets good psychometric principles, the next step was an inferential test to find out the relationship between the variables being tested. But before that, the researchers looked at the normality of each data tested (see table 1).

TABLE I. NORMALITY TEST OF VARIABLES

\begin{tabular}{|l|l|}
\hline \multicolumn{1}{|c|}{ Variable } & Kolmogorov-Smirnov Test \\
\hline Grade Point Average (GPA) & .109 \\
\hline Creativity (C) & .883 \\
\hline Critical Thinking Disposition (CTD) & .348 \\
\hline
\end{tabular}

From table 1, it can be seen that each variable has a normal distribution. This can be seen from the Kolmogorov value which is greater than .05 [2]. If the data used is normal, then the next analysis is correlational analysis (see table 2).

\section{TABLE II. CORRELATION BETWEEN VARIABLES}

\begin{tabular}{|c|c|c|c|}
\hline Variable & GPA & Creativity & CTD \\
\hline GPA & 1 & -.012 & $.179^{\prime}$ \\
\hline Creativity & -.012 & 1 & $.618 "$ \\
\hline $\begin{array}{c}\text { Critical } \\
\text { Thinking } \\
\text { Disposition }\end{array}$ & $.179^{\prime}$ & $.618 "$ & 1 \\
\hline
\end{tabular}


Table 2 shows that a significant and good correlation only occurs in the correlation of creativity and critical thinking disposition. The correlation between creativity and critical thinking disposition is .618 , while the other correlations are insignificant. Meanwhile, the researchers also looked at the ANOVA results which showed multiple regression of the effect of creativity and critical thinking disposition on the index of Grade Point Average (GPA) which showed a significance of .008 (<.05). Partially, creativity also has a significant effect with a significance level of .041. Meanwhile critical thinking disposition has a significant effect on GPA (Sig. 002, <.05). Over more, the $\mathrm{R}$ Square value is $5.6 \%$.

The results showed that the very high correlation between creativity and critical thinking disposition occurs because of several possibilities. Theoretically, these two attributes fall into the same realm of higher order thinking which allows them to be related to one another. Creativity and critical thinking are considered as initial indicators that someone needs to be successful in learning because these two things are closely related to how someone gets information and develops that information. In addition, the measuring tool used is self-report which could measure psychological conditions in the form of a person's attitude and tendency to behave. These reasons have been strengthened by several studies that support this notion [34-36].

\section{CONSLUSION}

This research concludes that creativity has a significant relationship with critical thinking. Creativity and critical thinking are grouped in higher order thinking skills in which these two aspects could become the indicators of the successful of learning process.

\section{ACKNOWLEDGMENT}

This study was conducted as a result of further collaboration between the Center for Assessment and Learning, Ministry of Education and Culture of Republic of Indonesia, Faculty of Psychology, UIN Sunan Gunung Djati Bandung, Faculty of Educational Sciences, Timor University, and Faculty of Education and Social Sciences, Indraprasta University Jakarta. Our thanks go to all respondents who have involved in this research.

\section{REFERENCES}

[1] I. Fahmi and Z. Ramdani, "Profil kekuatan karakter dan kebajikan pada mahasiswa berprestasi," Psympathic J. Ilm. Psikol., vol. 1, no. 1, pp. 98-108, 2014, doi: https://doi.org/10.15575/psy.v1i1.471.

[2] Z. Ramdani, "Construction of academic integrity scale," Int. J. Res Stud. Psychol., vol. 7, no. 1, pp. 87-97, 2018, doi: 10.5861/ijrsp.2018.3003.

[3] L. F. Tae, Z. Ramdani, and G. A. Shidiq, "Analisis tematik faktor-faktor yang mempengaruhi keberhasilan siswa dalam pembelajaran sains," Indones. J. Educ. Assesment, vol. 2, no. 1, p. 79, 2019, doi: 10.26499/ijea.v2i1.18.
[4] B. H. Prakoso, Z. Ramadani, and B. Rahmah, "Best Pratices of Character Education in Leading Schools in Bandung," Indones. J. Educ. Assesment, vol. 3, no. 1, p. 61, Jun. 2020, doi: 10.26499/ijea.v3i1.61.

[5] J. Nakamura and M. Dubin, Flow in motivational psychology, Second Edi., vol. 9. Elsevier, 2015.

[6] B. Lucas, "A five-dimensional model of creativity and its assessment in schools," Appl. Meas. Educ., vol. 29, no. 4, pp. 278-290, 2016, doi: 10.1080/08957347.2016.1209206

[7] S. Agnoli, M. Zanon, S. Mastria, A. Avenanti, and G. E. Corazza, "Enhancing creative cognition with a rapid right-parietal neurofeedback procedure," Neuropsychologia, vol. 118, no. February, pp. 99-106, 2018, doi: 10.1016/j.neuropsychologia.2018.02.015.

[8] J. Zhou, J. Shen, X. Wang, H. Neber, and I. Johji, "A cross-cultural comparison: Teachers' conceptualizations of creativity," Creat. Res. J., vol. 25, no. 3, pp. 239-247, 2013, doi: 10.1080/10400419.2012.730006.

[9] C. J. Fong, Y. Kim, C. W. Davis, T. Hoang, and Y. W. Kim, “A metaanalysis on critical thinking and community college student achievement," Think. Ski. Creat., vol. 26, pp. 71-83, 2017, doi: 10.1016/j.tsc.2017.06.002

[10] F. Warren, E. Mason-Apps, S. Hoskins, Z. Azmi, and J. Boyce, "The role of implicit theories, age, and gender in the creative performance of children and adults," Think. Ski. Creat., vol. 28, no. 2010, pp. 98-109, 2018, doi: 10.1016/j.tsc.2018.03.010.

[11] G. Krumm, M. Aranguren, V. Arán Filippetti, and V. Lemos, "Factor Structure of the Torrance Tests of Creative Thinking Verbal Form B in a Spanish-speaking Population," J. Creat. Behav., vol. 50, no. 2, pp. 150 164, 2016, doi: 10.1002/jocb.76.

[12] M. A. Taylor and J. L. Callahan, "Bringing Creativity Into Being: Underlying Assumptions That Influence Methods of Studying Organizational Creativity," Adv. Dev. Hum. Resour., vol. 7, no. 2, pp. 247-270, 2005, doi: 10.1177/1523422305274529.

[13] S. Agnoli, M. A. Runco, C. Kirsch, and G. E. Corazza, "The role of motivation in the prediction of creative achievement inside and outside of school environment," Think. Ski. Creat., vol. 28, no. May, pp. 167 176, 2018, doi: 10.1016/j.tsc.2018.05.005.

[14] J. Gralewski and M. Karwowski, "Are Teachers' Implicit Theories of Creativity Related to the Recognition of Their Students' Creativity?," J. Creat. Behav., vol. 52, no. 2, pp. 156-167, 2018, doi: 10.1002/jocb.140.

[15] H. Shin, C. G. Park, and H. Kim, "Validation of Yoon's Critical Thinking Disposition Instrument," Asian Nurs. Res. (Korean. Soc. Nurs. Sci)., vol. 9, no. 4, pp. 342-348, 2015, doi: 10.1016/j.anr.2015.10.004.

[16] J. Warsihna, Z. Ramdani, and B. H. Prakoso, "Using Kahoot to improve students' achievement and critical thinking in undergraduate of psychology students," in IADIS International Conference Cognition and Exploratory Learning in Digital Age 2019, 2019, pp. 144-150.

[17] M. Dehghani, F. Mirdoraghi, and H. Pakmehr, "The role of graduate students' achievement goals in their critical thinking disposition," Procedia - Soc. Behav. Sci., vol. 15, pp. 2426-2430, 2011, doi: 10.1016/j.sbspro.2011.04.121.

[18] H. Kaya, E. Şenyuva, and G. Bodur, "The relationship between critical thinking and emotional intelligence in nursing students: A longitudinal study," Nurse Educ. Today, vol. 68, pp. 26-32, 2018, doi: 10.1016/j.nedt.2018.05.024.

[19] N. C. Facione, P. A. Facione, G. Sanchez, and J. Gainen, "The disposition toward critical thinking," J. Gen. Educ., vol. 44, no. 1, pp. $1-$ 125, 1995, doi: 10.2307/27797240.

[20] P. A. Facione, "Critical thinking- A statement of expert consensus for purposes of educational assessment and instruction (The Delphi Report)," California State University, 1990.

[21] M. J. Bezanilla, D. Fernández-Nogueira, M. Poblete, and H. GalindoDomínguez, "Methodologies for teaching-learning critical thinking in higher education: The teacher's view," Think. Ski. Creat., vol. 33, p. 100584, 2019, doi: 10.1016/j.tsc.2019.100584 
[22] S. Tanyer, "The Role of Writing and Reading Self-efficacy in First-year Preservice EFL Teachers' Writing Performance," Procedia - Soc. Behav. Sci., vol. 199, pp. 38-43, 2015, doi: 10.1016/j.sbspro.2015.07.484.

[23] N. Castilla, C. Llinares, J. M. Bravo, and V. Blanca, "Subjective assessment of university classroom environment," Build. Environ., vol 122, pp. 72-81, 2017, doi: 10.1016/j.buildenv.2017.06.004.

[24] Z. Ramdani and B. H. Prakoso, "Integritas akademik: Prediktor kesejahteraan siswa di sekolah,” Indones. J. Educ. Assesment, vol. 2, no. 1, p. 29, 2019, doi: 10.26499/ijea.v2i1.14.

[25] Z. Ramdani, S. Amrullah, and L. Felisima Tae, "Pentingnya Kolaborasi dalam Menciptakan Sistem Pendidikan yang Berkualitas," MediaPSI, vol. 5, no. 1, pp. 40-48, 2019, doi: 10.21776/ub.mps.2019.005.01.4.

[26] Z. Ramdani, "Kolaborasi antara kepala sekolah, guru, dan siswa dalam menciptakan sistem pendidikan yang berkualitas," in PROSIDING 1st National Conference on Educational Assessment and Policy (NCEAP 2018) KOLABORASI, 2018, no. Nceap.

[27] M. Hansenne and J. Legrand, "Creativity, emotional intelligence, and school performance in children," Int. J. Educ. Res., vol. 53, pp. 264-268, 2012, doi: 10.1016/j.ijer.2012.03.015.

[28] F. A. D'Alessio, B. E. Avolio, and V. Charles, "Studying the impact of critical thinking on the academic performance of executive MBA students," Think. Ski. Creat., vol. 31, pp. 275-283, 2019, doi: 10.1016/j.tsc.2019.02.002.

[29] S. Chan and M. Yuen, "Personal and environmental factors affecting teachers' creativity-fostering practices in Hong Kong," Think. Ski. Creat., vol. 12, pp. 69-77, 2014, doi: 10.1016/j.tsc.2014.02.003.
[30] L. Niu, L. S. Behar-Horenstein, and C. W. Garvan, "Do instructional interventions influence college students' critical thinking skills? A metaanalysis," Educ. Res. Rev., vol. 9, pp. 114-128, 2013, doi: 10.1016/j.edurev.2012.12.002.

[31] C. Peterson and M. E. P. Seligman, Character strengths and virtues: A handbook and classification. United States of America: American Psychological Association, 2004.

[32] K. Banicki, "Positive psychology on character strengths and virtues. A disquieting suggestion," New Ideas Psychol., vol. 33, no. 1, pp. 21-34, 2014, doi: 10.1016/j.newideapsych.2013.12.001.

[33] Z. Ramdani, N. Azizah, N. Nuranisah Djamal, A. Abdul Rahman, and B H. Prakoso, An Integrated Assessment Of Critical Thinking Skills \& Dispositions To Prevent Hoax In Academic Context. 2019.

[34] K. Y. L. Ku, “Assessing students' critical thinking performance: Urging for measurements using multi-response format," Think. Ski. Creat., vol. 4, no. 1, pp. 70-76, 2009, doi: 10.1016/j.tsc.2009.02.001.

[35] D. Fung, "The pedagogical impacts on students' development of critical thinking dispositions: Experience from Hong Kong secondary schools," Think. Ski. Creat., vol. 26, no. November 2016, pp. 128-139, 2017, doi: 10.1016/j.tsc.2017.10.005

[36] K. Y. L. Ku, Q. Kong, Y. Song, L. Deng, Y. Kang, and A. Hu, "What predicts adolescents' critical thinking about real-life news? The roles of social media news consumption and news media literacy," Think. Ski. Creat., vol. 33, no. January, p. 100570, 2019, doi: 10.1016/j.tsc.2019.05.004. 